\title{
The trigeminal trophic syndrome
}

Figure Development of zoster-associated trigeminal trophic syndrome

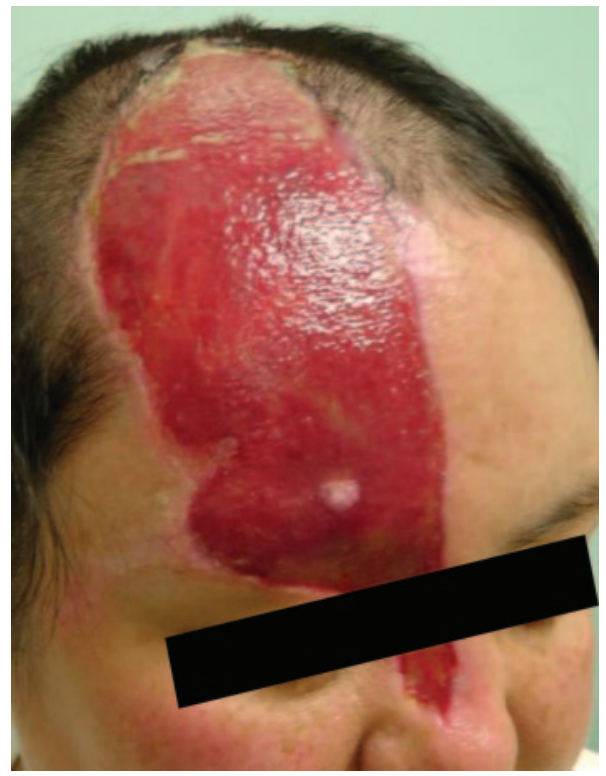

Weeks after surgical and radiation-induced zoster ophthalmicus, this patient developed trigeminal trophic syndrome, characterized by the triad of dysesthesias, anesthesia, and ulceration. Despite multiple treatments, the ulceration expanded over 8 years to include the nasociliary branch of the ophthalmic division of the trigeminal nerve.

A 21-year-old woman was irradiated after resection of a pituitary adenoma. A few weeks later, she developed right ophthalmic-distribution zoster and right abducens palsy. Zoster rash resolved, but persistent dysesthesias led to constant rubbing and scratching, ultimately leading to ulceration. Skin biopsy was negative for malignancy and chronic infection. Despite antibiotic, antiviral, triamcinolone, and hyperbaric oxygen treatment, the ulceration expanded (figure). The lesion is zoster-associated trigeminal trophic syndrome (TTS). TTS also occurs after trigeminal rhizotomy, alcohol injection, resection of acoustic neuroma, and pontine infarction. ${ }^{1}$ Because persistent radicular pain occurs without zoster, ${ }^{2}$ some cases of TTS may reflect zoster sine herpete.

Maria A. Nagel, MD, Don Gilden, MD, Aurora, CO

Author contributions: Dr. Nagel: drafted the manuscript for content, analyzed and interpreted the data. Dr. Gilden: drafted the manuscript for content, analyzed and interpreted the data.

Disclosure: Dr. Nagel receives research support from the NIH. Dr. Gilden has received a speaker honorarium from Merck Serono; serves as Senior Associate Editor for the Journal of Neurovirology and on the editorial boards of In Vivo, Journal of Virology, Scientific American Medicine, Virus Genes, and Neurology ${ }^{\circledR}$; and receives research support from the NIH.

Address correspondence and reprint requests to Dr. Don Gilden, Department of Neurology, University of Colorado School of Medicine, 12700 E. 19th Avenue, Mail Stop B-182, Aurora, CO 80045; don.gilden@ucdenver.edu

1. Litschel R, Winkler H, Dazert S, Sudhoff H. Herpes zoster-associated trigeminal trophic syndrome: a case report and review. Eur Arch Otorhinolaryngol 2003;260:86-90.

2. Gilden DH, Wright RR, Schneck SA, Gwaltney JM, Mahalingam R. Zoster sine herpete, a clinical variant. Ann Neurol 1994;35:530-533. 


\section{Neurology}

\section{The trigeminal trophic syndrome}

Maria A. Nagel and Don Gilden

Neurology 2011;77;1499

DOI 10.1212/WNL.0b013e318232ac46

\section{This information is current as of October 10, 2011}

\section{Updated Information \& Services}

\section{References}

Subspecialty Collections

Permissions \& Licensing

\section{Reprints}

including high resolution figures, can be found at: http://n.neurology.org/content/77/15/1499.full

This article cites 2 articles, 0 of which you can access for free at: http://n.neurology.org/content/77/15/1499.full\#ref-list-1

This article, along with others on similar topics, appears in the following collection(s):

All Clinical Neurology

http://n.neurology.org/cgi/collection/all_clinical_neurology

Neuropathic pain

http://n.neurology.org/cgi/collection/neuropathic_pain

Viral infections

http://n.neurology.org/cgi/collection/viral_infections

Information about reproducing this article in parts (figures,tables) or in its entirety can be found online at:

http://www.neurology.org/about/about_the_journal\#permissions

Information about ordering reprints can be found online:

http://n.neurology.org/subscribers/advertise

Neurology ${ }^{\circledR}$ is the official journal of the American Academy of Neurology. Published continuously since 1951, it is now a weekly with 48 issues per year. Copyright Copyright $@ 2011$ by AAN Enterprises, Inc.. All rights reserved. Print ISSN: 0028-3878. Online ISSN: 1526-632X.

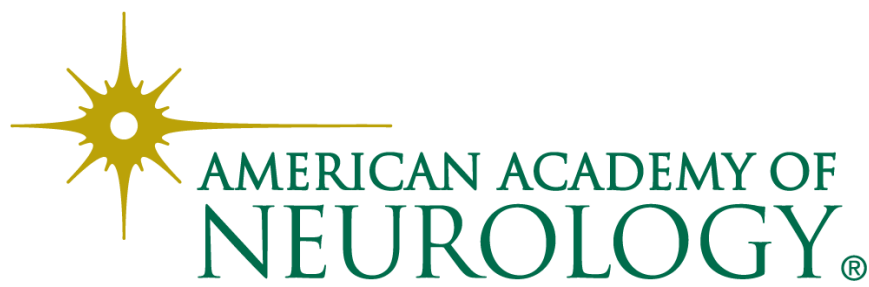

